\title{
Effect of spacing and number of seedlings per hill on the performance of aus rice cv. NERICA 1 under dry direct seeded rice (DDSR) system of cultivation
}

\author{
S. K. Bhowmik, M. A. R. Sarkar and F. Zaman \\ Department of Agronomy, Bangladesh Agricultural University, Mymensingh-2202, Bangladesh
}

\begin{abstract}
An experiment was conducted at the Agronomy Field Laboratory, Bangladesh Agricultural University, Mymensingh during the period from April to August 2011 to find out the effect of spacing and number of seedlings hill ${ }^{-1}$ on the performance of Aus rice cv. NERICA 1. Four spacing viz. $25 \mathrm{~cm} \times 15 \mathrm{~cm}, 20 \mathrm{~cm} \times 15 \mathrm{~cm} .20 \mathrm{~cm} \times 10 \mathrm{~cm}$ and $15 \mathrm{~cm} \times$ $10 \mathrm{~cm}$ and four number of seedlings hill ${ }^{-1}$ viz. 2, 3, 4 and 5 were included in the experiment. The experiment was laid out in a randomized complete block design with three replications. The highest number of total tillers $\mathrm{m}^{-2}$, number of effective tillers $\mathrm{m}^{-2}$, number of grains panicle $\mathrm{e}^{-1}$, grain yield, straw yield, biological yield and harvest index were obtained from $20 \mathrm{~cm} \times 10 \mathrm{~cm}$ spacing. Plant height and 1000- grain weight were not significantly affected by spacing. Number of seedlings hill ${ }^{-1}$ exerts a significant effect on plant height. The highest value of total tillers $\mathrm{m}^{-2}$, number of effective tillers $\mathrm{m}^{-2}$, total grains panicle ${ }^{-1}$, grain yield, straw yield, biological yield and harvest index were obtained from five seedlings hill ${ }^{-1}$. The interaction between spacing and number of seedlings hill ${ }^{-1}$ significantly influenced yield and plant characters. The highest number of effective tillers $\mathrm{m}^{-2}$, grains panicle ${ }^{-1}$, grain yield, straw yield and biological yield were recorded from the interaction between $20 \mathrm{~cm} \times 10 \mathrm{~cm}$ and five seedlings hill ${ }^{-1}$.
\end{abstract}

Keywords: Spacing, Number of seedlings per hill ${ }^{-1}$, Dry direct seeded rice (DDSR), NERICA

\section{Introduction}

Rice (Oryza sativa L.) is the staple food, of Bangladesh where it constitutes a major part of human diet. The total area and production of rice in Bangladesh are 11.35 million hectares and 31.975 million tons, respectively (BBS, 2010). Aus rice is cultivated on $8.9 \%$ of the total cropped area of Bangladesh (BBS, 2010). The national average yield of rice in Bangladesh is very low $\left(2.91 \mathrm{t} \mathrm{ha}^{-1}\right)$ compared to that of other rice growing countries (BBS, 2010). At the same time the total rice growing area is being continuously declined at about 0.61 per annum due to urbanization and industrialization. So attempts should be made to increase the yield per unit area. Under such condition there is no way out other than the development and adoption in yield increasing technologies. Among different management practices, use of appropriate number of seedlings hill ${ }^{-1}$ and spacing are important.

Plant spacing has an important role on growth and yield of rice. Optimum plant density ensures the plant to grow properly with their aerial and underground parts by utilizing more solar radiation and soil nutrients (Miah et al., 1990). Closer spacing hampers intercultural operations. Also in a densely populated crop, the inter-plant competition is very high for nutrients, air and light, which usually results in mutual shading, lodging and thus favours more straw yield than grain yield. On the other hand, under wider plant spacing desired hill unit ${ }^{-1}$ area cannot be obtained, which ultimately reduces yield unit ${ }^{-1}$ area. The maximum benefit can be derived from a rice field, if the crop is properly spaced between rows and within rows. Alam (2006) stated that optimum spacing gave a maximum number of total tillers $\mathrm{m}^{-2}$, maximum number of fertile tillers $\mathrm{m}^{-2}$ which was dependent on temperature, moisture and other soil factors. Shrirame et al. (2000) reported that total number of tillers hill $^{-1}$ was higher at the wider spacing. They also observed that two seedlings hill ${ }^{-1}$ gave significantly higher number of tillers hill ${ }^{-1}$ than three seedlings hill ${ }^{-1}$.

Number of seedlings hill ${ }^{-1}$ is an important factor for successful rice production because it affects plant population unit ${ }^{-1}$ area, availability of sunlight and nutrients, photosynthesis and respiration, which ultimately influence the yield contributing characters and yield (Chowdhury et al., 1993). Optimum number of seedlings hill ${ }^{-1}$ may facilitate the rice plant to grow properly both in its aerial and underground parts by utilizing maximum radiant energy, nutrient, space and water and also can reduce seedling cost. Excess number of seedlings hill ${ }^{-1}$ may produce higher number of tillers hill ${ }^{-1}$ resulting in shading, lodging and thus 
favor the production of straw instead of grain. On the other hand, the lesser number of seedlings hill ${ }^{-1}$ may cause insufficient tiller number, thus keeping space and nutrients underutilized and at the end, total number of panicles unit ${ }^{-1}$ area may be reduced resulting in poor gain yield. It is, therefore, necessary to determine the suitable number of seedlings hill $^{-1}$ for obtaining higher yield from a HYV of rice. Alam (2006) reported that highest number of total tillers and number of effective tillers were obtained from 2 seedlings hill $^{-1}$. Obulamma and Reddeppa (2002) revealed that one seedling hill ${ }^{-1}$ gave the highest grain yield, crop growth rate and net assimilation rate while 3 seedlings hill ${ }^{-1}$ had the highest dry matter prosecution, leaf area index and leaf area density. The study was undertaken to evaluate the effect of spacing and number of seedlings per hill on the performance of Aus rice cV. NERICA 1 under Dry Direct Seeded Rice (DDSR) system of cultivation.

\section{Materials and Methods}

An experiment was conducted at the Agronomy Field Laboratory, Bangladesh Agricultural University, Mymensingh during the period from April to August 2011. The land was medium high and the soil was silty-loam and well drained and its general fertility level was low. The soil of the experimental field was more or less neutral in reaction with $\mathrm{p}^{\mathrm{H}}$ value 6.5 and low in organic matter content (1.67\%). NERICA 1 was used as test crop in the experiment. The experiment consisted of four spacing viz. $25 \mathrm{~cm} \times 15 \mathrm{~cm}, 20$ $\mathrm{cm} \times 15 \mathrm{~cm} .20 \mathrm{~cm} \times 10 \mathrm{~cm}$ and $15 \mathrm{~cm} \times 10 \mathrm{~cm}$ and four numbers of seedlings hill ${ }^{-1}$ viz. 2, 3, 4 and 5 .

The experiment was laid out in a randomized complete block design with three replications. Each block was divided into 16 unit plots and size of the unit plot was $10 \mathrm{~m}^{2}(4.0 \mathrm{~m} \times 2.5 \mathrm{~m})$. The experimental land was first opened with a power tiller. Then the land was prepared by ploughing and cross-ploughing with a country plough and subsequently leveled by laddering. Weeds and stubble were removed from the field before sowing the seeds. The field layout was accomplished according to the experimental design adopted on 01 May 2011. Healthy seeds were selected by specific gravity method. Seeds were then immersed in a bucket of water for 24 hours. These seeds were then taken out of water and kept in incubation for 24 hours and then were sown directly in the main field. The experimental area was fertilized with 180-125-66-60-10 kg ha-1 of urea, triple super phosphate, muriate of potash, gypsum and zinc sulphate respectively. The entire amounts of triple super phosphate, muriate of potash, gypsum and zinc sulphate were applied at the time of final land preparation. Urea was applied in three equal splits. The first split of urea was applied at the time of final land preparation, the second split of urea was top dressed at 20 days after sowing (DAS) and the third split of urea was top dressed at 40 days after sowing (DAS). Crop management practices such as drainage, plant protection measures were done as per requirement and three weeding were done in order to keep the crop weed free at 15, 30 and 45 DAS. Initially 6 seeds were sown hill ${ }^{-1}$. After emergence, the seedling were thinned out to maintain the treatment $(2,3,4,5$ seedlings hill ${ }^{-1}$ ) in different plots.

At physiological maturity central $1 \mathrm{~m}^{2}$ area of each plot was harvested, sundried to record the data on plant height $(\mathrm{cm})$, number of total tillers $\mathrm{m}^{-2}$, number of effective tillers $\mathrm{m}^{-2}$, number of non-effective tillers $^{-2}$, number of grains panicle ${ }^{-1}$, number of sterile spikelets panicle ${ }^{-1}, 1000$-grain weight $(\mathrm{g})$, grain yield $\left(\right.$ tha $\left.^{-1}\right)$ and straw yield $\left(\mathrm{t} \mathrm{ha}^{-1}\right)$ were recorded from five randomly selected hills in each unit plot from the sampling area excluding border rows. The crop was harvested at maturity from a harvest area of $2.5 \mathrm{~m} \mathrm{x}$ $2.0 \mathrm{~m}$ in the middle portion of each unit plot. The grains and straws were sun dried converted to ton per hectare with $14 \%$ moisture content of grains. The biological yield and harvest index were calculated with the following formula:

Biological yield $=$ Grain yield + straw yield

Harvest index $(\%)=($ Grain yield/Biological yield $) \times 100$.

Collected data were analyzed statistically using MSTAT-C programme and the means were compared by Duncan s Multiple Range Test (Gomez and Gomez, 1984). 


\section{Results and Discussion}

Effect of spacing: Number of total tillers $\mathrm{m}^{-2}$, number of effective tillers $\mathrm{m}^{-2}$, number of grains spikelets ${ }^{-1}$, number of sterile spikelets panicle ${ }^{-1}$, grain yield, straw yield, biological yield and harvest index were significantly affected by different spacing (Table 1). The highest number of total tillers $\mathrm{m}^{-2}$, number of effective tillers $\mathrm{m}^{-2}$, number of grains panicle ${ }^{-1}$ were obtained in $S_{3}(20 \mathrm{~cm} \times 10 \mathrm{~cm})$ spacing and the lowest number of total tillers $\mathrm{m}^{-2}$, number of effective tillers $\mathrm{m}^{-2}$, number of grains panicle ${ }^{-1}$ were obtained in $\mathrm{S}_{1}(25 \mathrm{~cm} \times 15 \mathrm{~cm})$ spacing. The highest grain yield $\left(3.13 \mathrm{t} \mathrm{ha}^{-1}\right)$ was observed in $\mathrm{S}_{3}(20 \mathrm{~cm} \times 10 \mathrm{~cm})$ spacing. The highest number of effective tillers $\mathrm{m}^{-2}$ and the highest number of grains panicle ${ }^{-1}$ were mainly responsible for this highest grain yield. Grain yield obtained in $S_{4}(15 \mathrm{~cm} \times 10 \mathrm{~cm})$ spacing was statistically identical to the spacing $S_{3}(20 \mathrm{~cm} \times 10 \mathrm{~cm})$. The lowest grain yield $\left(1.85 \mathrm{t} \mathrm{ha}^{-1}\right)$ was obtained from $S_{1}(25 \mathrm{~cm} \times 15 \mathrm{~cm})$ spacing mainly because of the lowest number of effective tillers $\mathrm{m}^{-2}$ and the lowest number of grains panicle ${ }^{-1}$. Similar results were also obtained by Moniruzzaman (2003). The highest straw yield $\left(3.58 \mathrm{t} \mathrm{ha}^{-1}\right)$ was observed in $S_{3}(20 \mathrm{~cm} \times 10 \mathrm{~cm})$ spacing mainly because of the highest number of total tillers $\mathrm{m}^{-2}$. On the other hand, the lowest straw yield $\left(2.55 \mathrm{t} \mathrm{ha}^{-1}\right)$ was obtained from $\mathrm{S}_{1}(25 \mathrm{~cm} \times 15 \mathrm{~cm})$ spacing caused mainly due to the lowest number of total tillers $\mathrm{m}^{-2}$. The highest biological yield $\left(6.70 \mathrm{t} \mathrm{ha}^{-1}\right)$ and harvest index $(46.63 \%)$ were observed in $\mathrm{S}_{3}(20 \mathrm{~cm} \times 10 \mathrm{~cm})$ spacing. On the other hand, the lowest biological yield $\left(4.39 \mathrm{t} \mathrm{ha}^{-1}\right)$ was obtained from $\mathrm{S}_{1}(25 \mathrm{~cm} \times 15 \mathrm{~cm})$ spacing (Table 1).

Effect of number of seedlings hill ${ }^{-1}$ : Number of seedlings hill $^{-1}$ had significant effect on yield and yield contributing characters of Aus rice. The tallest plant was observed in two seedlings hill $^{-1}$. Five seedlings hill $^{-1}$ produced the shortest plant. It was observed that plant height showed a decreasing trend with the increase of number of seedling hill ${ }^{-1}$ and became the shortest one at five seedlings hill ${ }^{-1}$. The highest number of total tillers $\mathrm{m}^{-2}$, number of effective tillers $\mathrm{m}^{-2}$ and the highest number of grains panicle $\mathrm{e}^{-1}$ were found in five seedlings hill ${ }^{-1}$. The lowest number of total tillers $\mathrm{m}^{-2}$, number of effective tillers $\mathrm{m}^{-2}$ and the lowest number of grains panicle $\mathrm{e}^{-1}$ were found in two seedlings hill ${ }^{-1}$. The highest grain yield $\left(3.05 \mathrm{t} \mathrm{ha}^{-1}\right)$ was obtained at five seedlings hill ${ }^{-1}$. The highest number of effective tillers $\mathrm{m}^{-2}$ and the highest number of grains panicle ${ }^{-1}$ were mainly responsible for this highest grain yield. Grain yield decreased progressively with the decrease of number of seedlings hill $^{-1}$. The lowest grain yield $\left(2.19 \mathrm{t} \mathrm{ha}^{-1}\right)$ was found in two seedlings hill ${ }^{-1}$ because mainly of lowest number of effective tillers $\mathrm{m}^{-2}$ and lowest number of grains panicle ${ }^{-1}$. The highest straw yield $\left(3.57 \mathrm{t} \mathrm{ha}^{-1}\right)$ was produced by five seedlings hill ${ }^{-1}$ caused mainly due to the highest number of total tillers $\mathrm{m}^{-2}$. The lowest straw yield $\left(2.75 \mathrm{t} \mathrm{ha}^{-1}\right)$ was obtained from two seedlings hill $^{-1}$ because mainly of the lowest number of total tillers $\mathrm{m}^{-2}$. The highest biological yield $\left(6.63 \mathrm{t} \mathrm{ha}^{-1}\right)$ and harvest index (45.93\%) were obtained from five seedlings hill $^{-1}$. Weight of 1000 grains was not significantly affected by number of seedlings hill $^{-1}$ (Table 1 ).

Interaction effect of spacing and number of seedlings hill ${ }^{-1}$ : Interaction effect of spacing and number of seedlings hill ${ }^{-1}$ had significant on yield and yield contributing characters of Aus rice except plant height $(\mathrm{cm})$ and 1000-grain weight. The highest number of total tillers $\mathrm{m}^{-2}$ and number of grains panicle ${ }^{-1}$ were obtained from $\mathrm{S}_{3}(20 \mathrm{~cm} \times 10 \mathrm{~cm})$ spacing with five seedlings hill'. The highest grain yield $\left(3.53 \mathrm{t} \mathrm{ha}^{-1}\right)$ and straw yield $\left(4.02 \mathrm{t} \mathrm{ha}^{-1}\right)$ were obtained from the $S_{3}(20 \mathrm{~cm} \times 10 \mathrm{~cm})$ spacing with five seedlings hill ${ }^{-1}$ .The lowest grain yield $\left(1.46 \mathrm{t} \mathrm{ha}^{-1}\right)$ and straw yield $\left(1.98 \mathrm{t} \mathrm{ha}^{-1}\right)$ were obtained from $\mathrm{S}_{1}(25 \mathrm{~cm} \times 15 \mathrm{~cm})$ spacing with two seedlings hill ${ }^{-1}$. The highest biological yield $\left(7.55 \mathrm{t} \mathrm{ha}^{-1}\right)$ was recorded from $\mathrm{S}_{3}(20 \mathrm{~cm} \times$ $10 \mathrm{~cm}$ ) spacing with five seedlings hill ${ }^{-1}$ and the lowest biological yield $\left(3.44 \mathrm{t} \mathrm{ha}^{-1}\right)$ was obtained from $\mathrm{S}_{1}$ $(25 \mathrm{~cm} \times 15 \mathrm{~cm})$ spacing with two seedlings hill $^{-1}$ (Table 2).

Results revealed that plant spacing and number of seedlings hill ${ }^{-1}$ have considerable role in increasing yield of rice. Optimum plant density ensures the plant to grow properly. When the plant density exceeds the optimum level, competition among plants for light above ground or for nutrients below the ground become severe, consequently the plant growth slows down and the grain yield decreases. On the other hand, optimum number of seedlings hill ${ }^{-1}$ influences the tiller formation, solar radiation interception, total sunshine reception, nutrient uptake and other physiological phenomena and ultimately affects the growth and development of rice plant. Therefore, it can be concluded that spacing $20 \mathrm{~cm} \times 10 \mathrm{~cm}$ with five seedlings hill $^{-1}$ appears as the best combination to obtain maximum grain yield of aus rice cv. NERICA 1 under Dry Direct Seeded Rice (DDSR) system of cultivation. 
Table 1. Effect of spacing and number of seedlings hill $^{-1}$ on yield and yield contributing characters of aus rice cv. NERICA1

\begin{tabular}{|c|c|c|c|c|c|c|c|c|c|c|c|c|}
\hline Treatments & $\begin{array}{c}\text { Plant } \\
\text { height } \\
(\mathrm{cm})\end{array}$ & $\begin{array}{c}\text { Number } \\
\text { of total } \\
\text { tillers } \mathrm{m}^{-2}\end{array}$ & $\begin{array}{c}\text { Number } \\
\text { of } \\
\text { effective } \\
\text { tillers } \mathrm{m}^{-2}\end{array}$ & $\begin{array}{c}\text { Number } \\
\text { of non- } \\
\text { effective } \\
\text { tillers } \mathrm{m}^{-2}\end{array}$ & $\begin{array}{c}\text { Number } \\
\text { of } \\
\text { grains }^{-1} \\
\text { panicle }^{-1}\end{array}$ & $\begin{array}{l}\text { Number } \\
\text { of sterile } \\
\text { spikelets } \\
\text { panicle }^{-1}\end{array}$ & $\begin{array}{c}\text { Number } \\
\text { of total } \\
\text { spikelets } \\
\text { panicle }^{-1}\end{array}$ & $\begin{array}{c}1000- \\
\text { grain } \\
\text { weight } \\
\text { (g) }\end{array}$ & $\begin{array}{c}\text { Grain } \\
\text { yield } \\
\left(\mathrm{t} \mathrm{ha}^{-1}\right)\end{array}$ & $\begin{array}{c}\text { Straw } \\
\text { yield } \\
\left(\mathrm{t} \mathrm{ha}^{-1}\right)\end{array}$ & $\begin{array}{c}\text { Biological } \\
\text { yield } \\
\left(\mathrm{t} \mathrm{ha}^{-1}\right)\end{array}$ & $\begin{array}{c}\text { Harvest } \\
\text { index } \\
(\%)\end{array}$ \\
\hline \multicolumn{13}{|c|}{ Spacing (cm) } \\
\hline $\mathrm{S}_{1}$ & 92.40 & $138.25 d$ & $109.58 \mathrm{c}$ & 28.67 & $102.78 d$ & $31.64 a$ & $134.42 d$ & 23.94 & $1.85 \mathrm{c}$ & $2.55 b$ & $4.39 c$ & $42.10 \mathrm{~d}$ \\
\hline $\mathrm{S}_{2}$ & 93.16 & $145.75 c$ & $119.42 b$ & 26.33 & 107.60c & $28.85 b$ & $136.45 c$ & 24.53 & $2.47 b$ & $3.09 a b$ & $5.56 \mathrm{~b}$ & $44.38 \mathrm{c}$ \\
\hline $\mathrm{S}_{3}$ & 92.28 & $151.58 \mathrm{a}$ & $123.42 a$ & 28.17 & $124.65 a$ & $23.79 d$ & $148.45 a$ & 24.48 & $3.13 a$ & $3.58 a$ & $6.70 \mathrm{a}$ & $46.63 a$ \\
\hline $\mathrm{S}_{4}$ & 92.13 & $149.42 b$ & $122.50 a b$ & 26.92 & $112.98 \mathrm{~b}$ & $25.26 \mathrm{c}$ & $138.24 b$ & 24.50 & $2.97 a b$ & $3.50 \mathrm{a}$ & $6.47 a$ & $45.82 \mathrm{~b}$ \\
\hline CV (\%) & 4.12 & 4.36 & 5.24 & 4.26 & 6.33 & 5.45 & 5.78 & 6.59 & 7.45 & 6.31 & 4.18 & 5.85 \\
\hline $\begin{array}{l}\text { Level of } \\
\text { sig. }\end{array}$ & NS & ** & ** & NS & ** & ** & $\star \star$ & NS & $\star *$ & ** & $\star \star *$ & $\star \star$ \\
\hline \multicolumn{13}{|c|}{ Number of seedlings hill ${ }^{-1}$} \\
\hline 2 & $93.98 \mathrm{a}$ & $128.33 d$ & $99.00 \mathrm{~d}$ & $29.33 b$ & $90.33 d$ & $36.75 a$ & $127.08 \mathrm{c}$ & 24.00 & $2.19 \mathrm{~d}$ & $2.75 \mathrm{c}$ & $4.94 \mathrm{c}$ & $44.14 b$ \\
\hline 3 & $92.41 b$ & $128.11 \mathrm{c}$ & $103.22 \mathrm{c}$ & $24.89 c$ & $99.27 c$ & $26.26 \mathrm{~b}$ & $125.53 d$ & 24.08 & $2.37 c$ & $3.06 \mathrm{~b}$ & $5.42 b$ & $43.49 c$ \\
\hline 4 & $92.30 \mathrm{c}$ & $147.33 b$ & $122.44 b$ & $24.89 c$ & $119.52 b$ & $23.81 \mathrm{c}$ & $143.33 b$ & 24.63 & $2.80 \mathrm{~b}$ & $3.34 a b$ & $6.14 a$ & $45.38 a$ \\
\hline 5 & $91.27 d$ & $174.11 \mathrm{a}$ & $144.00 \mathrm{a}$ & $30.11 a$ & $138.90 \mathrm{a}$ & $22.73 d$ & $143.33 b$ & 24.75 & $3.05 a$ & $3.57 a$ & $6.63 a$ & $45.93 a$ \\
\hline CV (\%) & 4.12 & 4.36 & 5.24 & 4.26 & 6.33 & 5.45 & 5.78 & 6.59 & 7.45 & 6.31 & 4.18 & 5.85 \\
\hline $\begin{array}{l}\text { Level of } \\
\text { sig. }\end{array}$ & $\star *$ & $\star \star$ & ** & ** & ** & ** & ** & NS & ** & ** & ** & $\star \star$ \\
\hline
\end{tabular}

In a column, figures with same letter or without letter do not differ significantly whereas figures with dissimilar letters differ significantly (as per DMRT).

$* *=$ Significant at $1 \%$ level of probability. NS= Not significant.

$\mathrm{N}_{1}=2$ seedlings hill ${ }^{-1}, N_{2}=3$ seedlings hill $^{-1}, N_{3}=4$ seedlings hill ${ }^{-1}, N_{4}=5$ seedlings hill ${ }^{-1}$

$\mathrm{S}_{1}=25 \mathrm{~cm} \times 15 \mathrm{~cm}, \mathrm{~S}_{2}=20 \mathrm{~cm} \times 15 \mathrm{~cm}, \mathrm{~S}_{3}=20 \mathrm{~cm} \times 10 \mathrm{~cm}, \mathrm{~S}_{4}=15 \mathrm{~cm} \times 10 \mathrm{~cm}$

Table 2. Effect of interaction of spacing and number of seedlings hill ${ }^{-1}$ on yield and yield contributing characters of aus rice cv. NERICA1

\begin{tabular}{|c|c|c|c|c|c|c|c|c|c|c|c|c|}
\hline $\begin{array}{c}\text { Number of } \\
\text { seedlings } \\
\text { hill }^{-1} \times \\
\text { spacing }\end{array}$ & $\begin{array}{c}\text { Plant } \\
\text { height } \\
(\mathrm{cm})\end{array}$ & $\begin{array}{c}\text { Number } \\
\text { of total } \\
\text { tillers } \mathrm{m}^{-2}\end{array}$ & $\begin{array}{c}\text { Number of } \\
\text { effective } \\
\text { tillers } \mathrm{m}^{-2}\end{array}$ & $\begin{array}{l}\text { Number } \\
\text { of non- } \\
\text { effective } \\
\text { tillers } \mathrm{m}^{-2}\end{array}$ & $\begin{array}{l}\text { Numbers } \\
\text { of grains } \\
\text { panicle }^{-1}\end{array}$ & $\begin{array}{l}\text { Number } \\
\text { of sterile } \\
\text { spikelets } \\
\text { panicle }^{-1}\end{array}$ & $\begin{array}{l}\text { Number } \\
\text { of total } \\
\text { spikelets } \\
\text { panicle }^{-1}\end{array}$ & $\begin{array}{c}1000- \\
\text { grain wt } \\
\text { (g) }\end{array}$ & $\begin{array}{l}\text { Grain } \\
\text { yield } \\
\left(\mathrm{t} \mathrm{ha}^{-1}\right)\end{array}$ & $\begin{array}{c}\text { Straw } \\
\text { yield } \\
\left(\mathrm{t} \mathrm{ha}^{-1}\right)\end{array}$ & $\begin{array}{l}\text { Biological } \\
\text { yield } \\
\left(\mathrm{t} \mathrm{ha}^{-1}\right)\end{array}$ & $\begin{array}{c}\text { Harvest } \\
\text { index } \\
(\%)\end{array}$ \\
\hline $\mathrm{N}_{1} \times \mathrm{S}_{1}$ & 93.01 & $22.67 j$ & $4.00 \mathrm{~h}$ & $28.67 b-f$ & $74.30 \mathrm{~L}$ & $40.08 \mathrm{a}$ & $114.38 \mathrm{~h}$ & 23.87 & $1.46 \mathrm{~h}$ & & & 42.40ef \\
\hline $\mathrm{N}_{1} \times \mathrm{S}_{2}$ & 4.00 & & & $32.67 \mathrm{bc}$ & & $41.56 a$ & $127.72 \mathrm{f}$ & & $2.09 f$ & & & \\
\hline $\mathrm{N}_{1} \times \mathrm{S}_{3}$ & 93.44 & $134.67 \mathrm{~h}$ & $67 \mathrm{~g}$ & $21.00 \mathrm{c}-\mathrm{g}$ & & $31.52 b$ & $139.09 \mathrm{e}$ & 23.79 & $2.70 \mathrm{~cd}$ & $3.02 b c$ & & $7.20 \mathrm{a}$ \\
\hline $\mathrm{N}_{1} \times \mathrm{S}_{4}$ & 95.47 & 134 & & 26.67gh & & $33.82 b$ & $127.11 \mathrm{f}$ & 24.10 & 2 de & $3 \mathrm{bc}$ & & \\
\hline $\mathrm{N}_{2} \times \mathrm{S}_{1}$ & 3.34 & & & 31.0 & & $32.59 b$ & $113.49 \mathrm{~h}$ & & $1.81 \mathrm{~g}$ & $3 \mathrm{~cd}$ & & \\
\hline $\mathrm{N}_{2} \times \mathrm{S}_{2}$ & 92.59 & 132 & & 17.33h & & $26.87 \mathrm{~cd}$ & $119.77 \mathrm{~g}$ & 24.38 & $2.26 f$ & $2.98 \mathrm{bc}$ & & 09de \\
\hline $\mathrm{N}_{2} \times \mathrm{S}_{3}$ & .25 & & & 43.00d-g & & $21.60 \mathrm{fg}$ & 139.69de & 23.86 & $2.76 c$ & $28 \mathrm{~b}$ & & $70 \mathrm{~b}$ \\
\hline $\mathrm{N}_{2} \times \mathrm{S}_{4}$ & 91.48 & & & 26.3 & & 23.99def & $18 f$ & & code & $33 \mathrm{~b}$ & & $5 \mathrm{~cd}$ \\
\hline $\mathrm{N}_{3} \times \mathrm{S}_{1}$ & 91.78 & $142.00 \mathrm{~g}$ & $20.00 \mathrm{e}$ & $22.00 \mathrm{gh}$ & $11 \mathrm{~g}$ & $27.91 c$ & $143.31 d$ & 24.15 & $1.87 \mathrm{~g}$ & $2.45 d$ & $32 f$ & $29 d$ \\
\hline $\mathrm{N}_{3} \times \mathrm{S}_{2}$ & 93.63 & & & 23.00fgh & & 23.18efg & 142.23de & 24.55 & $47 \mathrm{e}$ & $2.97 \mathrm{bc}$ & $4 \mathrm{de}$ & $39 \mathrm{bc}$ \\
\hline $\mathrm{N}_{3} \times \mathrm{S}_{3}$ & 92.16 & $67 \mathrm{e}$ & Ode & 18.67b-e & & $22.16 \mathrm{fg}$ & $148.62 c$ & 25.12 & $51 a$ & $3.97 a$ & & $89 a$ \\
\hline $\mathrm{N}_{3} \times \mathrm{S}_{4}$ & 91.63 & $152.33 d$ & $122.67 \mathrm{bc}$ & 29.67h & & $21.99 \mathrm{fg}$ & 139.17e & 24.68 & $3.35 a$ & $3.95 a$ & & $95 b$ \\
\hline $\mathrm{N}_{4} \times \mathrm{S}_{1}$ & & & & $33.00 \mathrm{~b}$ & & 25.99cde & $166.51 \mathrm{a}$ & & & $3.13 b$ & & \\
\hline $\mathrm{N}_{4} \times \mathrm{S}_{2}$ & 92.42 & $174.67 \mathrm{~b}$ & & $32.33 \mathrm{bcd}$ & $132.31 d$ & 23.78def & $156.09 b$ & 24.92 & $3.08 b$ & $33 b$ & & $28 \mathrm{a}$ \\
\hline $\mathrm{N}_{4} \times \mathrm{S}_{3}$ & 91.27 & 181.00ab & $1.00 \mathrm{a}$ & 30.00 efg & $146.49 a$ & $19.89 \mathrm{~g}$ & $166.38 \mathrm{a}$ & 25.17 & $3 a$ & $4.02 a$ & & 46.73ab \\
\hline & 89.93 & & & $25.00 \mathrm{~b}-\mathrm{e}$ & & $21.24 \mathrm{fg}$ & $157.52 b$ & 25.24 & & $3.81 a$ & & $46.79 a$ \\
\hline & & & & & & & 5.78 & & & 6.31 & & 5.85 \\
\hline $\begin{array}{l}\text { Level of } \\
\text { sig. }\end{array}$ & NS & $\star *$ & ** & ** & $\star *$ & $* *$ & $\star *$ & NS & ** & ** & $\star *$ & $\star \star$ \\
\hline
\end{tabular}

In a column, figures with same letter or without letter do not differ significantly whereas figures with dissimilar letters differ significantly (as per DMRT).

$* *=$ Significant at $1 \%$ level of probability. NS $=$ Not significant.

$N_{1}=2$ seedlings hill ${ }^{-1}, N_{2}=3$ seedlings hill $^{-1}, N_{3}=4$ seedlings hill ${ }^{-1}, N_{4}=5$ seedlings hill ${ }^{-1}$

$\mathrm{S}_{1}=25 \mathrm{~cm} \times 15 \mathrm{~cm}, \mathrm{~S}_{2}=20 \mathrm{~cm} \times 15 \mathrm{~cm}, \mathrm{~S}_{3}=20 \mathrm{~cm} \times 10 \mathrm{~cm}, \mathrm{~S}_{4}=15 \mathrm{~cm} \times 10 \mathrm{~cm}$ 
Bhowmik et al.

\section{References}

Alam, F. 2006. Effect of spacing, number of seedlings hill ${ }^{-1}$ and fertilizer management on the performance of Boro rice cv. BRRI dhan29. M. S. Thesis, Dept. Agron., Bangladesh Agril. Univ., Mymensingh. pp. 24-27.

BBS (Bangladesh Bureau of Statistics). 2010. Statistical Yearbook of Bangladesh. Bangladesh Bur. Stat., Stat. Div., Minis. Plann., Govt. People's Repub. Bangladesh. Dhaka. p. 47-49.

Chowdhury, M.J.U., Sarker, A.U., Sarkar. M.A.R. and Kashem, M.A. 1993. Effect of variety and number of seedlings hill ${ }^{-1}$ on the yield and its components of late transplant Aman rice. Bangladesh J. Agril. Sci. 20(2): 311-316.

Gomez, K.A. and Gomez, A.A. 1984. Statistical Producers for Agricultural Research. A Wiley Int. Sci. Pub. John Wiley and Sons, New York, Brisbane, Singapore. pp.139-240.

Miah, M.H.N., Karim, M.A., Rahman, M.S. and Islam, M.S. 1990. Performance of Nizersail mutants under different row spacings. Bangladesh J. Train. Dev. 3(2): 31-34.

Moniruzzaman, M. 2003. Effect of wider spacing and younger seedlings on growth, yield and yield attributes of Boro rice varieties. M. S. Thesis, Dept. Agron., Bangladesh Agril. Univ., Mymensingh. pp. 103-107.

Obulamma, U.A. and Reddeppa, R. 2002. Effect of spacing and seedling number on growth and yield of hybrid rice. J. Res. ANGRAU. 30(1): 76-78.

Shrirame, M.D., Rajgire, H.J. and Rajgire, A.H. 2000. Effect of spacing and seedling number per hill on growth attributes and yields of rice hybrid under lowland condition. Indian J. Agron. 33 (3): 221-223. 